\title{
The Development and Performance Evaluation of Digital Museums towards Second Classroom of Primary and Secondary School - Taking Zhejiang Education Technology Digital Museum as an Example
}

\author{
https://doi.org/10.3991/ijet.v14i02.7897 \\ Zheng Ying ${ }^{(\varpi)}$, Yang Yuhui, Chai Huifang, Chen Mo and Zhang Jianping \\ Zhejiang University, Hangzhou, China \\ zhengying1988@163.com
}

\begin{abstract}
Currently, visiting museums is one activity that gaining its popularity from primary and secondary school students, which makes museum an important part of second classroom. However, this kind of educational activity is limited by several factors such as transportation, time and space, etc., which result in several defects such as limited visiting efficiency, lacks of evaluation for teaching achievements etc. To solve these problems, we put forward a countermeasure program of digital museums towards second classroom for primary and secondary school students. First, we analyzed the studies of second classroom based on the digital museums both in China and other countries. On the basis of such analysis, we took Zhejiang Education Technology Museum as a template to design and develop Zhejiang Education Technology Digital Museum. Then we used theory of pairing design to study the performance of the traditional museum education and the digital museum education respectively. Finally, we evaluated users' experience of Zhejiang Education Technology Digital Museum by carrying out a questionnaire survey.
\end{abstract}

Keywords - Digital museum, informal study, second classroom

\section{Introduction}

Other than classroom learning, informal learning refers to the way of learning new knowledge at any time and any place. It accounts for more than $75 \%$ of an individual's knowledge. [1] [2] In China, informal learning of primary and secondary school mainly involves second classroom learning beyond formal learning inside school. Visiting museum is one activity that is getting much popular from primary and secondary school students and becomes an important part of second classroom. [3] Although second classroom based on museum visiting has been widely carried out in China and many achievements have been made, but there are still some defects. From organizational perspective, students need their parents in company to visit museums and they rely on public transportation which takes a lot of time. As a result, it is difficult to visit the same museum for many times. From educational perspective, limited 
physical space of museums resulted in limited knowledge capacity, which cannot provide students with sufficient information and knowledge in demand. In addition, museum visiting is a kind of flexible informal learning activities in lack of evaluation mechanism. Therefore, how to provide a more efficient learning environment for primary and secondary school students based on museums is one urgent issue to be studied.

Digital museum, also named virtual museum, refers to the museum which is presented on Internet by using virtual reality technology, graphic image technology and human-computer interaction technology. [4] [5] Digital museum has great potential in the presentation of cultural heritage because it can vividly present cultural heritage without damaging or destructing cultural heritage; [6] The increasing use of information and communication technologies (ICT) in museums is providing curators with new opportunities for the display of cultural heritage content, making it possible to merge real and digital works of art in a coherent exhibition space. [7] It is not constrained by time and space, easy for maintenance and content updates, and the costs are much less than traditional museum. [8] Surveys indicate that more and more users prefer to visit digital museums, meanwhile many organizations have begun to attach importance to the construction of digital museums. [9] Based on the analysis above and funded by Education Technology Center of Zhejiang Province, we began the construction of Zhejiang Education Technology Digital Museum as second classroom for primary and secondary school. We then apply it to second classroom study and evaluation.

\section{Overview of Digital Museums towards Second Classroom}

In countries other than China, great importance has been attached to activities like second classroom in museums. Digital museums have been constructed accordingly and a large amount of thematic learning programs have been designed for students in second classroom. More and more students tend to acquire knowledge from digital museums. British Museum open a specialized learning program in its digital museum, including school education, family education, adult education and discovery center etc., which covers students of different ages and designs different learning sheets according to students' understanding ability of different age to offer convenient access to second classroom learning; [10] The latest generation of cultural guides includes various kinds of multimedia content, to convey information about the cultural artifacts but especially to improve the visitor's experience by offering a personalized access to that information. [11] In this context, visitors become active elements, able to discover cultural content and share it through social recommendation sites on social media. [12] Louvre Museum offers a virtual tour in the digital museum and users can easily browse part of the content of the traditional museum. An art learning module consists of different sections as Animated Stories, Children's Perspective, Artistic Elements and Mini Site, etc. is set up to satisfy students' demands for second classroom; [13] In American Museum of Natural History, a Learn and Teach Module as second classroom is designed for students, $[14]$ which offers targeted services accord- 
ing to the role selection (teachers, parents and adults), the age of the students (kindergarten to grade 2, 3-5 grade, 6-8 grade, 9-12 grade, high school and above), the nature of the visiting group (family visit and class visit) and the visit theme; Metropolitan Museum of Art set up a learning module in the digital museum to provide E-learning resources for students and parents in second classroom activities based on students' age and parents' selected tasks. [15] These digital museums have all designed learning modules and learning activities to offer convenient access for students to second classroom, but most of them adopts Two-dimensional presentation methods, which are lack of immersive experience. In addition, due to commercial factors, it is difficult to obtain better understanding of the historical and cultural content without visiting the traditional museum.

Researches by western countries on museum education started earlier than China. Since 2007, it has developed in rapid pace, but mainly concentrated in the field of digital museum. Taking Web of Science as an example, in the research involved digital museum, the co-occurrence analysis of keywords is shown as figure 1, which indicates that foreign researches on digital museums are more comprehensive and they involve many aspects such as technology development, digital museum and cultural heritage protection etc. Timeline of Co-citation clustering of digital museum as figure 2 .

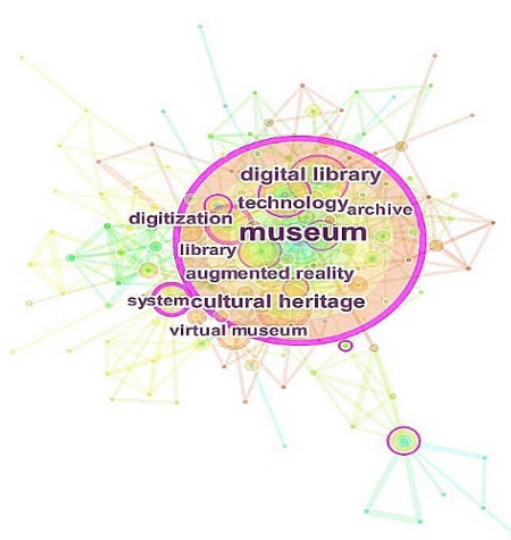

Fig. 1. Keyword co-occurrence analysis of digital museum based on WOS

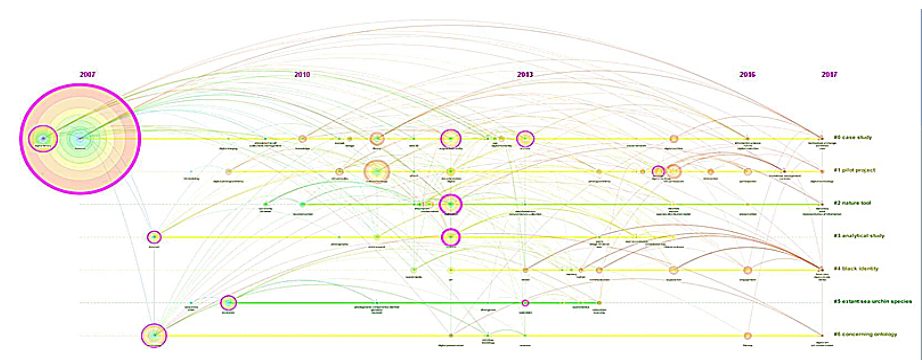

Fig. 2. Timeline of Co-citation clustering of digital museum based on WOS 
But, the researches based on the second classroom or secondary school are not sufficient. Taking the Web of Science an example again, the amount of literature based on museum and second classroom since 2007 is only 12 . However, the number of published articles is on the increase. The amount of literature based on museum and secondary school since 2007 is 124 , and the co-occurrence analysis of their keywords indicates that current foreign researches based on museum and secondary school mainly focus on museum teaching strategy but researches on digital museum and learning evaluation are rare, which is shown as figure 3 . Timeline of Co-citation clustering of secondary school based on museum is shown as figure 4 .

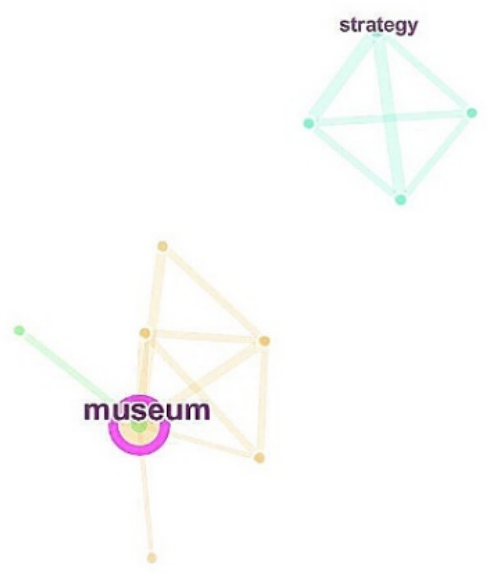

Fig. 3. Keyword co-occurrence analysis of Secondary School in museum based on WOS

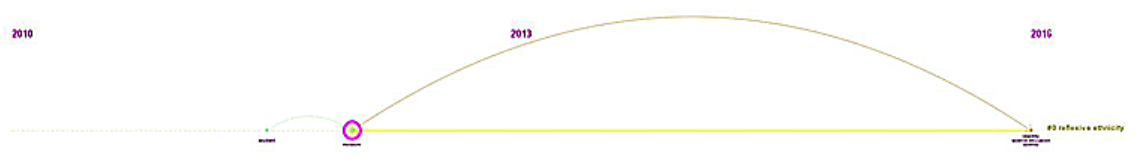

Fig. 4. Timeline of Co-citation clustering of Secondary School in museum based on WOS

Since 2008, all the museums in China have been opened to the public for free and museum is becoming an important learning site for the second classroom of primary and secondary school. [16] There are more and more studies on second classroom based on museum. Take How Net as an example, Keyword co-occurrence analysis of second classroom based on museum is as figure 5. It indicates that current Chinese researches on second classroom based on museum mainly focus on the adolescents' well-rounded education and higher vocational education based on traditional museum. Research on digital museum and learning evaluation is rare. Timeline of Co-citation clustering of Second classroom in museum based on HowNet is shown in figure 6 . 
Many of current Chinese national and provincial museums have digital museums and some of them have created panoramic virtual exhibition halls to present the content, such as Imperial Palace Museum, Henan Museum, Anhui Museum, etc. An attempt to make mobile technologies more shareable between visitors is the 'Mobile Digital Museum', a completely itinerant digital exhibition designed for the Inner Mongolia Museum in China. [17] Some public education activities are also provided in the National Museum. Chinese digital museums have certainly made achievements, but it is still lack of immersive digital environment based on virtual reality for those digital museums. Besides, there are basically no professional learning activities designed especially for second classroom, therefore it cannot attract more students.

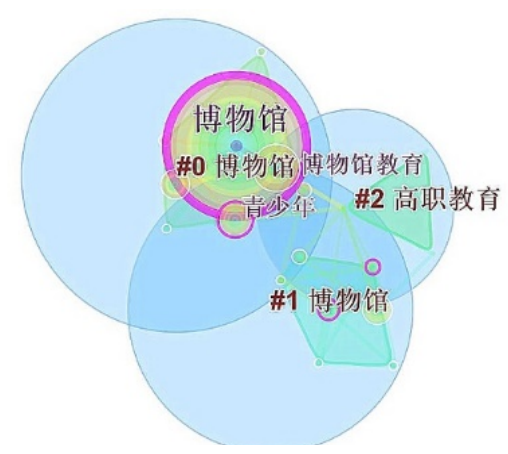

Fig. 5. Keyword co-occurrence analysis of Second classroom in museum based on HowNet

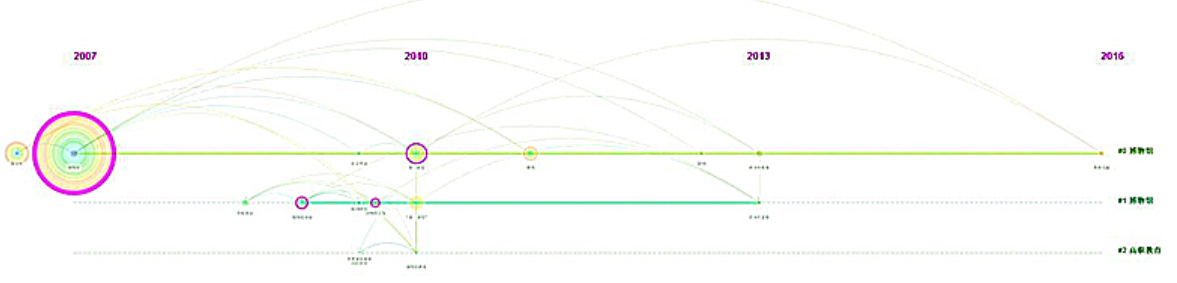

Fig. 6. Timeline of Co-citation clustering of Second classroom in museum based on HowNet

\section{Designing and Development of Zhejiang Education Technology Digital Museum}

Based on the analysis of researches reports, experts' judgment on technology and education, and supported by Education Technology Center of Zhejiang Province, we develop the Zhejiang Education Technology Digital Museum in four aspects: digital content presentation gaming-like experience, learning activity design and education evaluation. 


\subsection{Theoretical support}

Constructivism emphasizes learners' initiative and believes that learning is the process for learners to form the meaning and construct the understanding based on their own existing knowledge and experience, among which the scene, cooperation, dialogs and construction of meaning play indispensable roles ${ }^{[18]}$. Students' learning in second classroom based on digital museum is their active construction process of self-experience. Gaming-like learning process emphasizes on applying elements of game design to learning experience, such as gaming environment, human-computer interaction, fascinating plot and gaming mechanism, etc., so as to promise high participation, viscosity and loyalty for the users. ${ }^{[19]}$ Researches show that many primary and secondary school students love animation, video, games and other digital resources ${ }^{[20]}$; Tower Theory considers that the more specific the experience is, the easier people can understand. Therefore, learning should be a gradual transition from the concrete content to abstract content. Based on above analyses, the designers of digital museum should not only create immersive learning environment, simulated situational roles, and carry out flexible collaborative learning, integrate gaming elements with viscous mechanism, but also pay attention to the way they present these specific and vivid digital contents.

\subsection{Demand analysis and design objectives}

Zhejiang Educational Technology Digital Museum is mainly developed for primary and secondary school students who seek for more immersive, interesting and interactive digital experience. When browsing Zhejiang Education Technology Digital Museum, students are required to take a free tour of the museum from first-person perspective, try using various teaching tools to understand the development history of education technology, the benefits bought by those teaching tools, and explore the scientific principles behind the teaching tools. The objective is to get the same experience as visiting traditional museums, meanwhile overcome the defects caused by time, transportation, distance, space and other factors, and provide convenience for carrying out second classroom in primary and secondary school based on museums.

\subsection{Developing technology and system framework}

Developing technology: Constructed by Web3D virtual reality technology, Zhejiang Educational Technology Digital Museum is created with an interesting, immersive, interactive and exploratory second classroom-learning environment from students' perspective. The developing technologies applied are presented on table 1 . 
Paper-The Development and Performance Evaluation of Digital Museums...

Table 1. The technologies applied to developing the system of Zhejiang Educational Technology Digital Museum

\begin{tabular}{|l|l|}
\hline Software and language & \multicolumn{1}{c|}{ Application } \\
\hline Photoshop CS6 & $\begin{array}{l}\text { Used for all the image editing work during the development of Zhejiang Educa- } \\
\text { tional Technology Digital Museum }\end{array}$ \\
\hline Autodesk 3dsmax 2012 & $\begin{array}{l}\text { Used for 3D model creation for Zhejiang Educational Technology Digital } \\
\text { Museum }\end{array}$ \\
\hline Unity3D 4.5.5 & $\begin{array}{l}\text { Used for virtual scene design and interactive design of inquiry-based learning } \\
\text { in Zhejiang Educational Technology Digital Museum. }\end{array}$ \\
\hline Krpano 1.19 pr8 & $\begin{array}{l}\text { Used for all panoramic and circular scene of Zhejiang Educational Technology } \\
\text { Digital Museum }\end{array}$ \\
\hline Java /html & $\begin{array}{l}\text { For loading and presenting all graphic resources in Zhejiang Educational } \\
\text { Technology Digital Museum and responsible for the data communication } \\
\text { between all the programs and databases }\end{array}$ \\
\hline
\end{tabular}

System framework: The system framework of Zhejiang Educational Technology Digital Museum is divided into two parts: foreground and background. The foreground is mainly for student users to visit the museum and the background is for management of the museum, which refers to figure 7 .

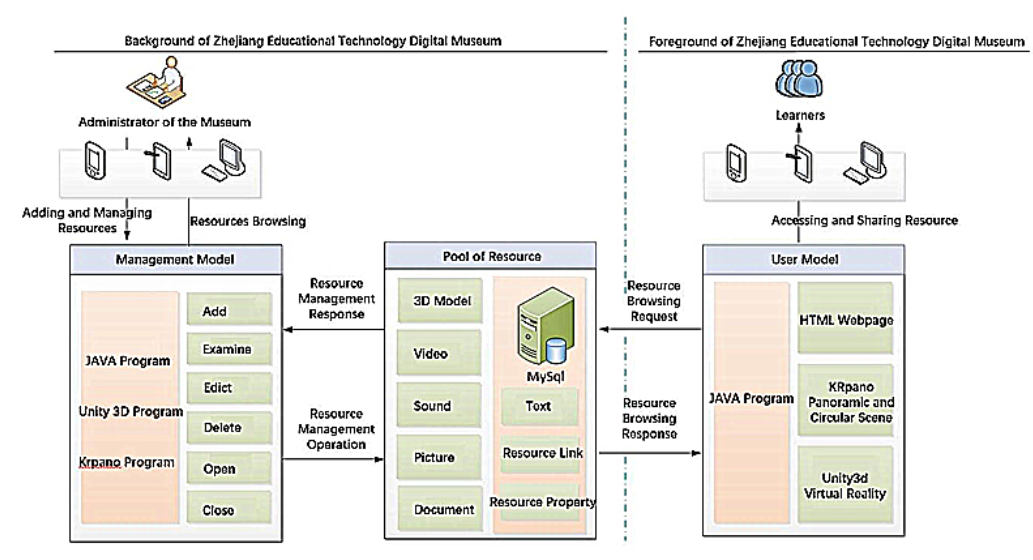

Fig. 7. System framework of Zhejiang Educational Technology Digital Museum

In the foreground, when students access to the digital museum through terminal devices such as mobile phones, computers and tablets, requests will be sent to the Mysql database by JAVA programs. Then the Mysql database will response to the browsing requests, presenting all the resources including 3D models, links, videos, voices, pictures, texts and documents to the students in the form of web pages, panoramic and circular scene and virtual reality. In the background, the administrator's access to the management module of the digital museum by terminal devices such as computers and mobile phones to add, edit, examine, delete the resources in the recourse base through JAVA program, Unity3d program and Krpano program. Mysql database will response to the administrators' operation requests through JAVA program, thus completing management of the digital museum. 


\subsection{Content and functions}

Zhejiang Education Digital Museum is divided into five modules: a. Educational Technology Exploration Pavilion; b. Educational Technology Exhibition Hall; c. Famous Educationists and Historical Archives; d. Inquiry-based Learning Module. f. Interactive Quizzes.

Educational technology exploration pavilion: Educational Technology Exploration Pavilion includes contents for exploration such as Intelligent Classroom Environment, Campus Bus Safety Monitor System, Cloud-computing based Online Classroom, Task Analysis Based on Big Data, 3D Printers, DisLab Innovative Experiment, Interactive Digital Microscopic Laboratory, Virtual Telestudio and Intelligent Voice system for Personalized Language Learning. The usability of the user interface has been a primary concern from the early days, since an easy-to-use interface could increase the level of cognitive engagement, so leading to a better learning process. when users perceive the interaction with technology as being intuitive and interactive, they experience higher levels of cognitive engagement. ${ }^{[21]}$ Based on the real museum, we use Unity3d to simulate Intelligent Classroom and show students an intelligent teaching environment where they can control sound, light and electricity. We use gaming like interactive design to simulate modern teaching instrument, creating immersive experience for students. In such environment, students are able to experience development of modern educational technology. In this Pavilion, we provide two modes for students--- a virtual instructor tour and an independent exploration tour. It would be very convenient for students that they can follow the instructor to understand the content in the pavilion or choose to independently explore in the pavilion. As shown in figure 8 .

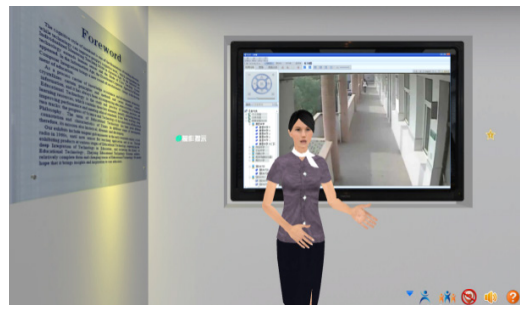

(a).Virtual tour guide simulation

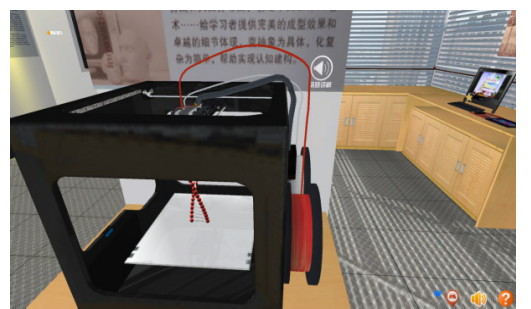

(c) DNA model printer simulation

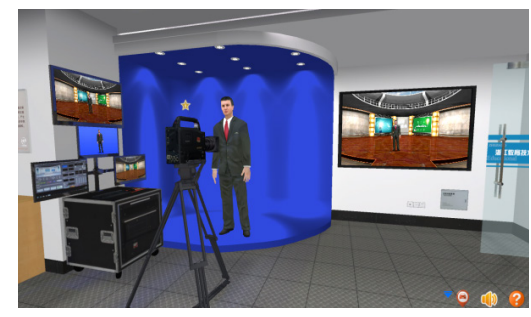

(b).Synthesis principle simulation in virtual studio video

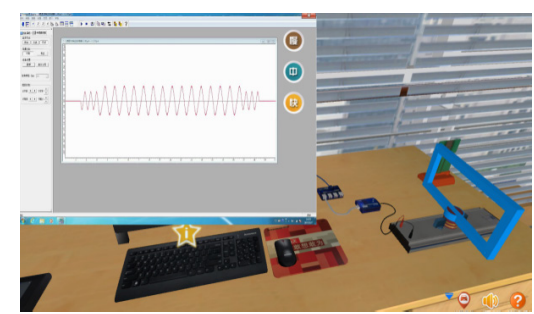

(d) Electromagnetic induction principle simulation

Fig. 8. Simulation of educational technology experience pavilion 
Educational technology exhibition hall: Educational Technology Exhibition Hall mainly present the development of educational technology in Zhejiang Province with nearly 300 teaching instruments for different subjects in primary and secondary school, as shown in table 2.

Table 2. Contents of educational technology exhibition hall

\begin{tabular}{|c|c|c|}
\hline Theme & Module & Content \\
\hline \multirow{5}{*}{$\begin{array}{l}\text { Development of educa- } \\
\text { tional technology in } \\
\text { Zhejiang Province }\end{array}$} & Origin of Educational Technology & $\begin{array}{l}\text { Education documents and teaching wall charts } \\
\text { etc. of Republic of China }\end{array}$ \\
\hline & 1950s -Cultural Revolution & $\begin{array}{l}\text { Establishment of Zhejiang Audio-Visual Educa- } \\
\text { tion Center, implement of Technology Educa- } \\
\text { tion, etc. }\end{array}$ \\
\hline & The Period of Cultural Revolution & $\begin{array}{l}\text { The educational system with combination of } \\
\text { education and labor; agricultural teaching aids. } \\
\text { etc. }\end{array}$ \\
\hline & $1970 \mathrm{~s}-90 \mathrm{~s}$ & $\begin{array}{l}\text { Establishment of classroom with electri- } \\
\text { cal audio-visual aids, promotion of radio and } \\
\text { television. etc. }\end{array}$ \\
\hline & 1990s- & $\begin{array}{l}\text { Establishment of Educational Technology } \\
\text { Center, popularization of information } \\
\text { technology education. etc. }\end{array}$ \\
\hline \multirow{9}{*}{$\begin{array}{l}\text { Development of teach- } \\
\text { ing aids for various } \\
\text { subjects in primary and } \\
\text { secondary schools }\end{array}$} & Chemistry teaching instruments & $\begin{array}{l}\text { chemicals, gas voltammeter, and sulfuric acid } \\
\text { model. etc. }\end{array}$ \\
\hline & Physics teaching instruments & Balance, Faraday disk, hand generator. etc. \\
\hline & Geography teaching instruments & Globe, seismograph, anemometer. etc. \\
\hline & Biology teaching instruments & $\begin{array}{l}\text { Human anatomy model, cell model and DNA } \\
\text { model. etc. }\end{array}$ \\
\hline & $\begin{array}{l}\text { Film and projection teaching } \\
\text { instruments }\end{array}$ & $\begin{array}{l}135 \text { day slide projector, film projector, portable } \\
\text { projector. etc. }\end{array}$ \\
\hline & Recording teaching instruments & $\begin{array}{l}\text { CF666 tape recorder, electronic tube type disc } \\
\text { recorder.etc. }\end{array}$ \\
\hline & Video teaching instruments & $\begin{array}{l}\text { AVC32501 black and white camera, } \\
\text { SONY5850 video recorder.etc. }\end{array}$ \\
\hline & Computer teaching instruments & $\begin{array}{l}286-486 \text { computer, Pentium series } \\
\text { computer.etc. }\end{array}$ \\
\hline & Other teaching instruments & $\begin{array}{l}\text { Lettering steel plate, BF3 scanner, } 212 \text { vector } \\
\text { scope device. etc. }\end{array}$ \\
\hline
\end{tabular}

The Digital Exhibition Hall Adopts live shooting and Krpano 1.19 PR8 software to create a series of panoramic scenes for students in this hall, then connected to complete and real museum environment by means of anchor link. Roaming map, film navigation, automatic roam and interactive spinning and zooming buttons with Gamebased UI are set up to provide convenience for students to explore the pavilion. In addition, when students click the presenting items, the system will pop up the details to help students enhance the understanding of teaching instruments. As shown in 


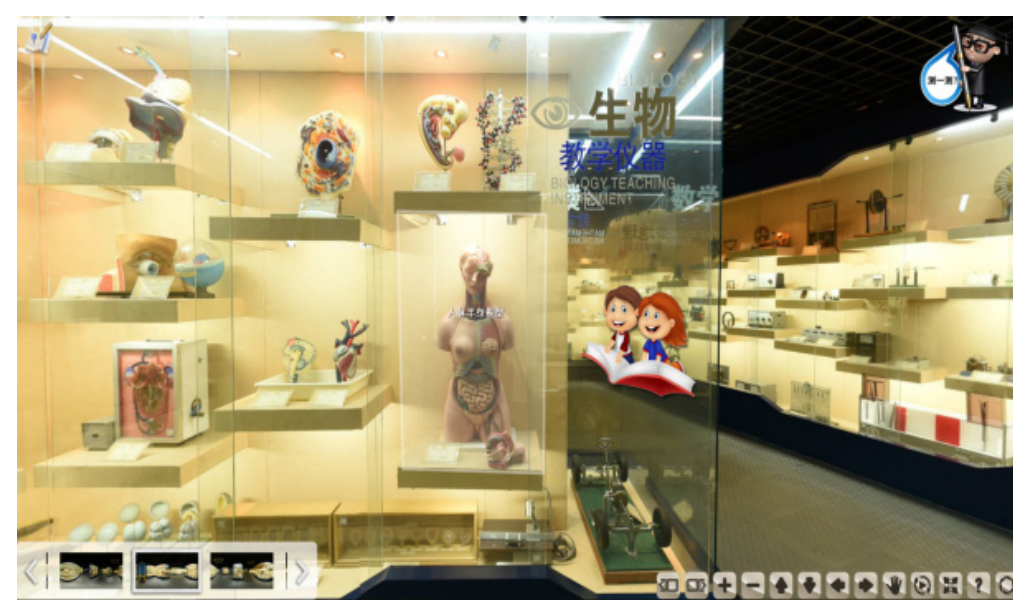

Fig. 9. Digital panoramic display of educational technology exhibition Hall

Famous educationists and historical archives: The module of Famous Educationists and Historical Archive includes famous figures of education in Zhejiang Province from the era of Republic of China and important historical moments after the establishment of Zhejiang Audio-Visual Education Center. The main contents are old photos and texts, therefore, we use JAVA to compile the HTML webpage, presenting in simple forms of graphics.

Inquiry-based learning module: Inquiry-based Learning Module is designed specifically for improving students' ability of exploration and practice, which provide students with learning sheets including a series of tasks such as $3 \mathrm{D}$ printer, crystal receiver and automotive gearshift system, which is as shown in figure 10 .

As a matter of fact, research in education indicates that learning results from psychological processes such as enjoyment [22], and emotions [23] [24]. Emotions or affect has been integrated into many research frameworks, such as the affective response model [25] and the cognitive-affective model of perceived user satisfaction. [26] Recent published studies especially reinforce emotions deserve further attention in the context of technology-mediated learning. [27] Perceived hedonic value played the most important mediating role transmitting the effects of flow on students' continuance intention. [28] Therefore, it is very important to stimulate learners' positive attitude and interest in learning. The learning sheet is designed based on the actual demand of daily life, which leads students to understand the subject knowledge in real life. The subsequent step of the learning sheets after students' understanding the background knowledge, is a virtual interactive task to solve practical problems, meanwhile evaluate how well students master the knowledge. Students can gain success through continuous experiments, so as to obtain the ability to acquire the knowledge and solve practical problems. 


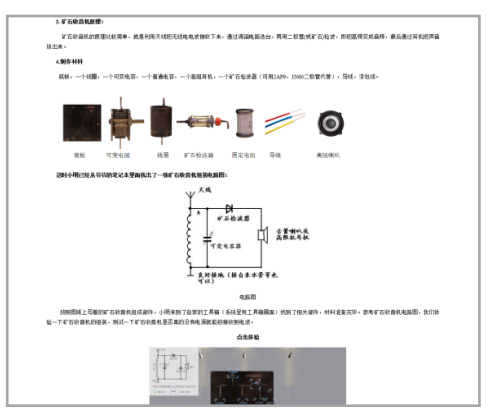

a) Crystal receiver worksheet of inquiry learning

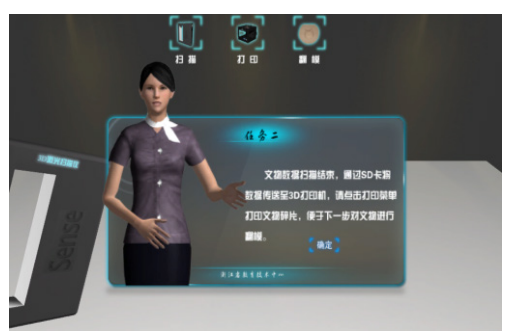

(c) 3D printing and heritage restoration

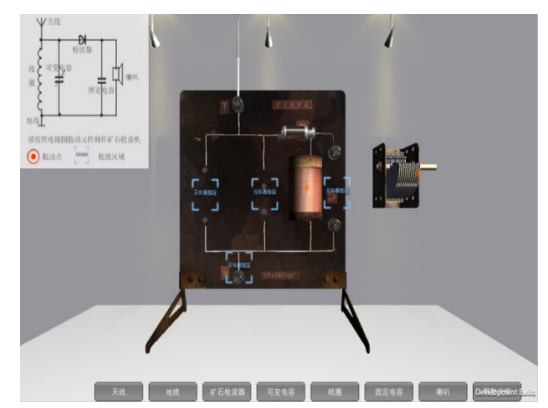

(b) Production of crystal receiver of inquiry learning

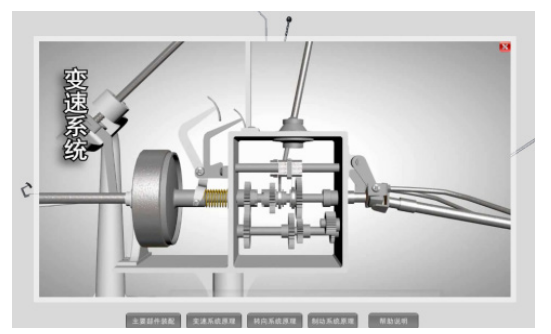

(d) Automotive gearshift system of inquiry learning

Fig. 10.Examples of inquiry learning

Interactive quizzes: In traditional museum, it is difficult to evaluate students' visiting learning effect and there is a lack of learning evaluation mechanism for a very long time due to various factors such as the limitation of space and changes of flows of visitors. But in the digital museum these kinds of factors do not exist. As digital technology occupies a large part of individuals' life, more and more researches are focusing on interaction. ${ }^{[29]}{ }^{[30]}$ Therefore, we set up an Interactive Quizzes module in Zhejiang Education Technology Digital Museum. This module takes the developing history of educational technology in Zhejiang Province, the identification of teaching instruments and the knowledge principle contained in primary and secondary schools as the core contents, and multiple-choice questions as the main form for student users. Students complete the test in sequence. The system will evaluate their tests and show them the correct answer after they finish the test. The system will rank the results, as shown in figure 11 . 

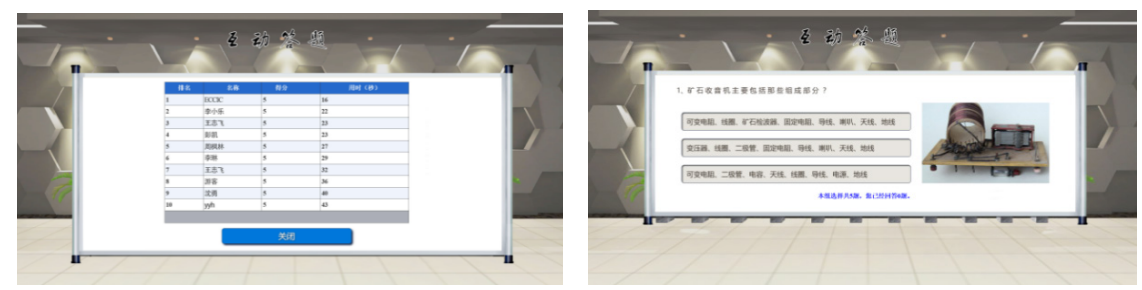

Fig. 11.Interactive Quizzes test and ranking

\section{$4 \quad$ Application and Evaluation}

Taking Hangzhou Xixing Secondary School as an example, we carried out an application research on second classroom. In accordance with the principle of paired design, 40 second-year junior high school students were selected for the test. These 40 students were divided into Group A and Group B (20 students in each group) and paired according to their gender and academic achievement. Group A is based on the traditional museum of Zhejiang Education Technology and Group B is based on Zhejiang Education Technology Digital Museum. They both took a second classroom study for two weeks. Students from both groups carried out self-initiated learning without teachers' organization. At the end every student took a test consists of 20 questions selected from the Interactive Quizzes System. The total score of the test is 10 points. The data of all the student's scores were analyzed by Spss 20.0 software, and compared by method of Paired T-Test. The results showed that the learning achievement of Group B is higher than that of Group A $(\mathrm{P}<0.01)$. As is shown in Table 3 and Table4.

Table 3. Frequency of students' score in Group A and Group B

\begin{tabular}{|c|c|c|}
\hline Scores & Number $-($ Group A) & Number - (Group B) \\
\hline $0 \sim$ & 0 & 0 \\
\hline $3 \sim$ & 3 & 5 \\
\hline $5 \sim$ & 9 & 10 \\
\hline $7 \sim$ & 6 & 4 \\
\hline $9 \sim 10$ & 2 & 20 \\
\hline Total & 20 & \\
\hline
\end{tabular}

Table 4. Statistical analysis of students' score in two groups

\begin{tabular}{|c|c|c|c|c|}
\hline $\mathbf{n}$ & Group A & Group B & t & P \\
\hline 40 & $6.90 \pm 1.77$ & $7.20 \pm 1.61$ & -10.728 & $<0.01$ \\
\hline
\end{tabular}

Note: Two sets of data conform to Normal Distribution and have the homogeneity of variance.

We sent a questionnaire to 30 students who has visited Zhejiang Education Technology Digital Museum, asking about their degree of satisfaction with Zhejiang Education Technology Digital Museum, and advantages comparing with with the traditional museum, as shown in Figure 12: 




(a) Survey on experience satisfaction of Zhejiang Education Technology Digital Museum

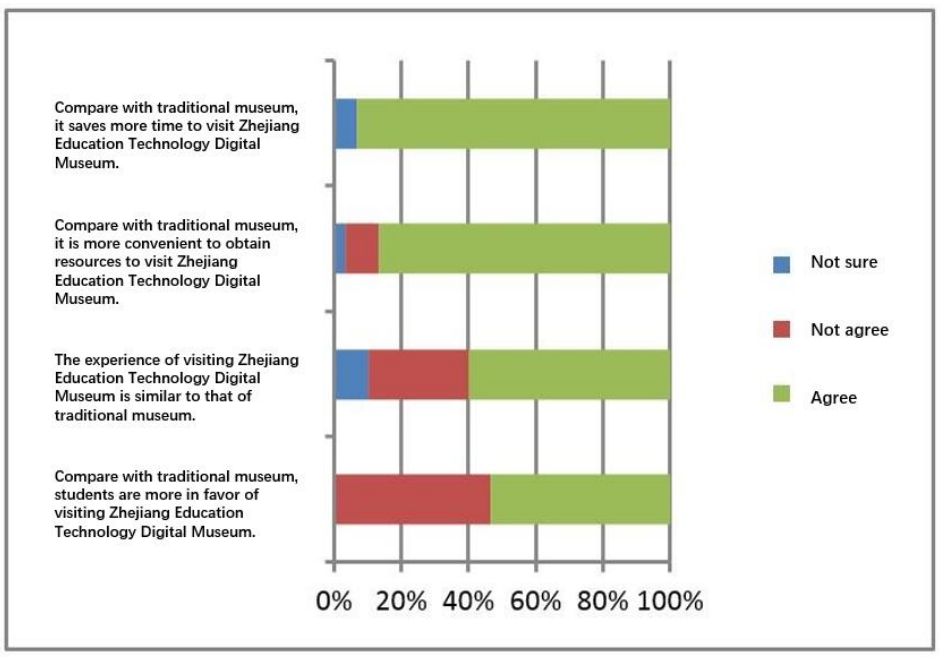

(b) Survey on advantages of Zhejiang Education Technology Digital Museum compared with the museum of physical

Fig. 12.Survey on experience of Zhejiang Education Technology Digital Museum

According to Figure 12(a), students are more satisfied with the digital museum for features of easy usability, immersive experience, high interactivity and the way resources are presented etc. According to figure 12(b), most of the students think that it is more timesaving to visit the digital museum than the traditional one and much easier to access to the resources. They believe they can obtain similar experience from digital museum. The number of students who are in favor of visiting the digital museum is even higher than the those in favor of the traditional museum. 


\section{Conclusion}

By analyzing the defects of application of traditional museum to second classroom in primary and secondary school and based on the traditional museum resources, we created Zhejiang Education Technology Digital Museum and applied it to second classroom in primary and secondary school. Comparing the students' performance in traditional museum with the one in digital museum in second classroom samples, we discover that the average learning achievement based on digital museum is higher than the one based on traditional museum. According to the questionnaire, we discover that majority of the students are satisfied with Zhejiang Education Technology Digital Museum in total and they consider second class learning based on digital museum is more efficient and convenient to access to the resources. Students can obtain similar experience from digital museum to that from traditional museum and they are more favor of digital museum.

Compared with traditional museums, digital museums have more advantages, but the number of students in favor of visiting digital museum is very close to the one in favor of traditional museum according to the questionnaire result. However, the digital museums cannot replace the role of traditional museums in second classroom in primary and secondary students, for the authenticity of presented items, parent-child activities, entertainment activities and deep learning in the realistic environment cannot be replaced by virtual experience.

\section{Acknowledgement}

Humanities and Social Sciences Youth Fund of Ministry of Education "Research on the Construction of Digital Museum in The New Rural Area and Preservation Strategy of Local Culture"; Project Number: Yang Yuhui [15YJCZH205].

\section{$7 \quad$ References}

[1] Shengquan Yu, Fang Mao. Informal Learning- A New Field of e-Learning Research and Practice [J]. China Educational Technology, 2005(10):18-23.

[2] Galanis, N., Mayol, E., Alier, M., Garcia-Penalvo, F. J. Supporting, evaluating and validating informal learning. A social approach. Computers in Human Behavior [J]. 2016(55):596-603.

[3] Weihong Song. Museum and Youth Education Activities [J]. Museum Research, 2015(4):31-35.

[4] Koukopoulos, D., Koukoulis, K A Trustworthy System with Mobile Services Facilitating the Everyday Life of a Museum. International Journal of Ambient Computing and Intelligence[J].2018(9):1-18.

[5] Huhtamo E. On the origins of the virtual museum [J]. Museums in a Digital Age, 2010: 121-135.

[6] Gomes L, Olga R P B, Silva L. 3D reconstruction methods for digital preservation of cultural heritage [J]. Pattern Recognition Letters, 2014, 50(C):3-14. https://doi.org/10.10 $\underline{\text { 16/j.patrec.2014.03.023 }}$ 
Paper-The Development and Performance Evaluation of Digital Museums...

[7] Caggianese. G, Gallo. L, Neroni. P. Evaluation of spatial interaction techniques for virtual heritage applications: A case study of an interactive holographic projection [J]. Future Generation Computer Systems, 2018, 81: 516-527. $\underline{\text { https://doi.org/10.10 }}$ 16/j.future.2017.07.047

[8] Sandra Kemp .Design museum futures: Catalysts for education [J]. Futures.2017 (94):5975. https://doi.org/10.1016/j.futures.2017.04.002

[9] Kabassi K. Evaluating websites of museums: State of the art [J]. Journal of Cultural Heritage, 2016, 24:184-196. https://doi.org/10.1016/j.culher.2016.10.016

[10] A. Chianese, F. Marulli, F. Piccialli, P. Benedusi, J.E. Jung. An associative engines-based approach supporting collaborative analytics in the internet of cultural things[J]. Future Generation Computer Systems.2017(66):187-198 https://doi.org/10.1016/j .future.2016.04.015

[11] M. Hong, J.J. Jung, F. Piccialli, A. Chianese, Social recommendation service for cultural heritage, Personal and Ubiquitous Computing [J]. 21 (2) (2017) 191-201. https://doi.org/10.1007/s00779-016-0985-x

[12] British Museum - Welcome to the British Museum [EB/OL]. http://www.british museum.org. 2017.4.21.

[13] Louvre Museum[EB/OL]. http://www.louvre.fr/en/ 2017.4.21.

[14] American Museum of Natural History [EB/OL]. http://www.amnh.org/ 2017.4.21.

[15] The Metropolitan Museum of Art [EB/OL]. http://www.metmuseum.org/ 2017.4.21.

[16] Yingying Wang. Museum and Adolescents' Well-rounded Education [J]. Museum Research, 2011, 2011(2):46-47.

[17] I.M. Museum, Mobile digital museum-the frontier for cultural heritage exhibitions, 2016. www.digitalmeetsculture.net/article/mobile-digital-museumthe-frontier-for-culturalheritage-exhibitions.2017.4.21.

[18] Yongfeng Wang, Kekang He. International Frontier Research Review Constructivist Learning Environment [J]. China Educational Technology, 2010(3):8-15.

[19] Xueying Bao, Yuxiang Zhao. Research on Progress and Prospect of Game-Based Learning [J]. China Educational Technology, 2015(8):45-52.

[20] Hao Shu, Yingfeng Ma. Analysis and Reflection of Online Learning of Primary and Secondary School in China [J]. China Educational Technology, 2014(23):19-22.

[21] J. Pallud, Impact of interactive technologies on stimulating learning experiences in a museum [J]. Information \& Management. 54 (4) (2017) 465-478. https://doi.org/10.1 016/j.im.2016.10.004

[22] A.C.H. Lin, W.D. Fernandez, S. Gregor, Understanding web enjoyment experiences and informal learning: a study in a museum context [J]. Decision Support Systems. 53 (2012) 846-858. https://doi.org/10.1016/j.dss.2012.05.020

[23] R.F. Baumeister, J.L. Alquist, K.D. Vohs, Illusions of learning: irrelevant emotions inflate judgments of learning [J]. Journal of Behavioral Decision Making. 28 (2015) 149-158. https://doi.org/10.1002/bdm.1836

[24] D. Finch, M. Peacock, D. Lazdowski, M. Hwang, Managing emotions a case study exploring the relationship between experiential learning, emotions, and student performance [J]. The International Journal of Management Education.13 (2015) 23-36. https://doi.org/10.1016/i.ijme.2014.12.001

[25] P. Zhang, The affective response model: a theoretical framework of affective concepts and their relationships in the ICT context [J]. MIS Quarterly. 37 (2013) 247-274. http s://doi.org/10.25300/MISQ/2013/37.1.11 
Paper-The Development and Performance Evaluation of Digital Museums...

[26] C.K. Coursaris, W. Van Osch, A Cognitive-Affective Model of Perceived User Satisfaction (CAMPUS): The complementary effects and interdependence of usability and aesthetics in IS design [J]. Inf. Manag. 53 (2016) 252-264.

[27] I. Rodríguez-Ardura, A. Meseguer-Artola, E-learning continuance the impact of interactivity and the mediating role of imagery, presence and flow [J]. Inf. Manag. 53 (2016) 504516.

[28] Z. Guo, L. Xiao, C. Van Toorn, Y. Lai, C. Seo, Promoting online learners' continuance intention: an integrated flow framework[J]. Inf. Manag. 53 (2016) 279-295. https://d oi.org/10.1016/j.im.2015.10.010

[29] Brancati, N., G. Caggianese, M. Frucci, L. Gallo, and P. Neroni. Experiencing Touchless Interaction with Augmented Content on Wearable Head-mounted Displays in Cultural Heritage Applications [J]. Personal and Ubiquitous Computing. 21(2017): 203-217. https://doi.org/10.1007/s00779-016-0987-8

[30] Wen-Chia Wang. Understanding user experience of news applications by Taxonomy of Experience (ToE) [J]. Behaviour \& Information Technology, 36:11 (2017), 1137-1147. https://doi.org/10.1080/0144929X.2017.1359337

\section{Authors}

Zheng Ying is with the College of Education of Zhejiang University, Hangzhou, and 310027 China (e-mail: zhengying1988@163.com).

Yang Yuhui (Corresponding author) is with the Modern Educational Technology Center of Zhejiang University, Hangzhou, and 310027 China (e-mail: zju_edu@ 163.com).

Chai Huifang is with the Modern Educational Technology Center of Zhejiang University, Hangzhou, and 310027 China (e-mail: chaihf@zju.edu.cn).

Chen Mo is with the Modern Educational Technology Center of Zhejiang University, Hangzhou, and 310027 China (e-mail: cmandhxj@zju.edu.cn).

Zhang Jianping is with the College of Education of Zhejiang University, Hangzhou, and 310027 China (e-mail: 21zjp@vip.163.com).

Article submitted 26 October 2017. Resubmitted 14 March, 27 May, and 05 July 2018. Final acceptance 10 July 20187 . Final version published as submitted by the authors. 